\title{
Editorial
}

\section{Aspects of Treaty Overriding}

\author{
Mr. Yann Kergall Coopers \& Lybrand, Paris'
}

Within an increasing number of countries, treaty shopping becomes an issue for the local fiscal authorities to deal with in an attentive manner. First, this issue is at present reflected by the general principles of a DTT (Double Taxation Treaty) policy. As an example, observing the US-European DTT policy proves the drafting of more and more comprehensive, complex and lengthy limitations of benefits clauses. The most recent example of such a clause, seems to be provided for by the newly drafted US-Netherlands DTT which should enter into force 1 January 1994 . Second, this issue is also reflected by an increasing number of domestic measures in order to limit DTT benefits. It may be noticed that just a couple of months ago Germany finally established a debt-equity ratio, thus limiting the debt-financing of a local subsidiary by its foreign shareholder.

However, as shown below, certain measures intended to override a DTT by local legislation may lose some of their significance. At least, this may take place within the European Community. Moreover, nowadays it even seems thinkable for an EC taxpayer to invoke EC-based treaty overriding mechanisms in his favour, thus reducing his tax burden beyond a given DTT.

In addition to a 'limitations of benefits' clause included within a given DTT, domestic legislation serves as well to combat such situations considered to be 'abnormal'. It is used by a considerable number of States to tax certain profits which should not be taxable according to the wording of a DTT. Obviously, a DTT cannot provide for sufficient shelter against such a practice unless the local jurisdiction recognizes that international conventions may by no means be waived by local law. In the US, for example, treaty overrides cannot be prevented for constitutional reasons and it is consequently easy to have them entered into force legally. The situation in Germany is quite different: in principle, a DTT prevails over German domestic tax legislation. Nevertheless, even the German government saw no major legal obstacle when dramatically extending its controlled foreign company legislation in the summer of 1992. Those examples demonstrate that treaty overriding by domestic law has almost never been considered to be virtually impossible because of international rules. Although from a legal point of view, it is more or less difficult for different States to overrule a binding convention entered officially into force, in practice a violation of international law does not really constitute a major obstacle. Consequently, we all had and have to live with that practice.

Although the Treasuries are not very likely to accept it easily, a change of this somewhat 'disrespectful' way to deal with international conventions may occur within the common market. The French approach to apply general anti-abusive clauses may serve to illustrate further that issue:

Article 209B of the French Tax Act provides, in principle, for the attribution of the income of a passive controlled foreign company located in a tax haven country prior to its actual distribution. This provision constitutes a remarkable exception of the general French parent-subsidiary scheme permitting to receive tax-free dividends from any 10 per cent participation. The wording of that article does not exclude its application even if a treaty exists between the controlled foreign company's home State and France.

Although it has not been applied in the past, the French fiscal authorities have expressly reserved the right to do so in the future. So far, no French court decision on that subject of applicability has been taken.

That issue is likely to improve its importance under the growing European Market. In this respect, the Irish Finance Centres seem to be a particularly interesting subject. As those finance centres have been created with the approval of the European Commission, the application of Article 209B by French Fiscal Authorities would constitute an infringement of Juridique et Fiscal, Paris FRANCE for his assistance. 
an existing treaty as well as of $\mathrm{E}^{\circ} \mathrm{C}$ legislation providing for the right of free movement of capital (and free establishment).

The compatibility of Article 209B with general EC legislation seems indeed rather questionable. The principal goal of EC tax harmonization and the European market comprises the free flux of capital without obstacles. Given that principle it remains rather doubtful whether under EC legislation it is within the power of an EC Member State to build up such obstacles.

Is Article 209B finally applicable to the Irish Finance Centres, thus indeed overriding the Irish-French treaty? Obviously, the answer will depend on whether the EC legislation is to be applied by French courts. On the application of EC Directives, the Cour de Cassation has adopted the position of the European Court of Justice on the application of multinational EC legislation. It has accepted that the Treaty establishing the EC and the legislation based upon it constitute an independent legal system prevailing over domestic legislation. The Conseil d'Etat, on the other hand, has developed its own, more restraining position on that subject. However, that dispute should not affect the application of the Treaty establishing the EC itself. As a conclusion, there are good reasons to believe that sometimes a taxpayer may successfully invoke the argument that EC legislation actually has the power to block the French anti-avoidance rules, by denying any such domestic treaty overriding by Article 209B.

It is true that, in the past, the term treaty overriding has usually been associated with failure of treaty protection. An example has just been given above by Article 209B of the French Tax Act. Consequently, this term has sometimes suffered from a bad image among tax counsels practicing in the international field. However, favourable aspects of that somewhat nasty term may nowadays also be discovered. A taxpayer may find himself in a situation to seek relief from an unfavourable DTT provision by claiming explicitly a treaty overriding. In tax literature, several example of such situations where a bilateral treaty may come into conflict with multilateral EC legislation have already been discussed.

Herein, two cases will briefly be discussed. First, it may well be possible to overrule the limitation of benefits clauses as concluded in a number of recent treaties between the US on the one hand and France, Italy, Spain, Belgium and Germany on the other hand. If, for example, a French company receives US-sourced income via a passive 100 per cent holding company resident in Germany, the treaty benefits may be denied as the holding company's shareholder is not a German resident. However, under multilateral EC legislation each EC resident disposes of the unreserved right to set up subsidiaries in another Member State. As such a limitation of benefits clause would limit a taxpayer's unreserved right of free establishment, the question arises whether the bilateral treaty or the EC multinational legislation should prevail. Given the framework of the common market and related developments, discrimination against EC resident holding companies goes indeed firmly against EC legislation.

Second, it may be asked whether a taxpayer could invoke the anti-discrimination clauses in order to waive a DTT's provision in his favour. Recently, Herzig/Dautzenberg (Der Betrieb 1992, p. 2519) examined the following question: It is supposed that a Belgium frontier worker in Germany is subject to a less favourable German tax treatment under the BelgiumGermany DTT than that which would be applicable to a Netherlands frontier worker under the Netherlands-German DTT. It is clear that the differences between the two treaties concluded by Germany will reflect the different tax systems of the countries involved, i.e., The Netherlands and Belgium. However, is there really a good reason that benefits granted by Germany to Netherlands nationals cannot be granted to Belgian nationals as well? If the answer is no, such an attitude may very well trigger discrimination against the Belgian national.

If the answer is yes only because of the fiscal consequences (i.e., lower tax yield of Germany), would not such an argument result in a justified violation of EC legislation any time financial matters are relevant. Herzig/Dautzenberg comes to the conclusion that Article 7 of the Treaty establishing the EEC does indeed under certain circumstances prohibit the discrimination of non-residents with respect to other non-residents. And should be checked whether this result is to be transferred to any of the EC Member States.

It is certain that treaty overriding will remain an important issue. No Treasury department is willing to relinquish its possibilities of domestic anti-abusive legislation because of EC legislation. In addition, in the past there has been no real reinforcement of violation of international tax law. However, in cases where a violation of international tax law involves also a violation of EC legislation it may now become more difficult to pursue the present treaty overriding practices. Moreover, the EC Member States may be forced to accept that treaty overriding, which has always been a State procedure to increase tax may also turn into a taxpayer's instrument to reduce tax. 